\title{
Software Trends in Improving Local Tourism Product Marketing in Indonesia: A Systematic Review
}

\author{
H. Purnomo \\ STIE Manajemen Bisnis, Indonesia \\ Corresponding authoremail: maspur@upi.edu
}

\begin{abstract}
Software is believed to be increasingly the prima donna of today's computerized era. This is because the world is getting easier to reach with digital assistance, which is becoming more and trendier. Tech is lagging in travel business activities. Many tourism business people are now increasingly interested in conducting their tour promos online to quickly increase local tourism products' marketing to the international market. So to ensure correctness, we have undertaken a practical study with literature reviews and travel publications. We prioritize the latest literature between 2015 and 2021, considering that the digital world is changing rapidly. To get valid and convincing results, we choose a coding analysis system, in-depth evaluation so that the conclusions we get an answer to this study's problems. Because this study relies on current data from searches from Google doc data, ERIC publications, Google scholarships, and other data sources is the main source. With the consideration of the existing literature, we conclude that now tourism actors in many countries are increasingly using digital applications in marketing tourism products in the world market share. Hopefully, this finding will provide meaningful input for all parties engaged in the tourism sector.
\end{abstract}

Keywords---digital trend, marketing method, qualitative review studies, tourism promotion.

\section{Introduction}

Software or digital has become a trend in every human activity, including in business and the economy. Now the question is why digital or software is widely used in business, especially in marketing. The answer is because this tool applies to the best internet or online applications. So it is possible to be connected with many people of local and even international nationality through the implementation of blogs, websites, e-mails, and social media networks, and other platforms (Todor, 2016; Toffler, 1970; Toffler, 1980). The reason is digital marketing easily reaches many potential consumers everywhere. Also almost all business people including those who are tourism support business activists where they can approach this online database. Bassano et al. (2019) said that locations and tourist destinations could be assisted by an internet search application. For example, Businessman can do good business content marketing and customers can use the location to find optimal marketing anywhere.

Businessmen with digital technology can call their customers from rural villages as long as there are technological tools. They don't have to look for potential buyers in the city. As long as they are proficient with the use of technology in certain social networks or social media, so it is true that many people today like social media for economic reasons and friendship or educational purposes.

With a digital approach, business people can carry out many business activities such as promotions or what we call advertising (Hassan \& Rahimi, 2016; Lau \& Lee, 1999). Then they can meet many who try to promote to do marketing on various platforms, can be on social media via email through Clinton promotions, even yes, such as tags or instant tags to promote products or currently people around the world can enter their radio and on their radio too. being able to find or receive promotions or advertisements is very practical (Hudson \& Hudson, 2017; Slater \& Narver, 1995; Hifza et al., 2020).

Before we go any further now, let us take a look at what digital marketing and software marketing means that many people understand. For that term, a simple understanding is when people say software marketing or internet marketing, it is a distant business, but it is marketed to market a product or service. Utilize digital tools and 
economical products can use the internet, which is defined by the software. The problem will arise if many people do not understand what technology, such as software, is because many business people do not all know precisely how to deal with the internet, which these experts say is the most advanced technology of the modern century. Adi (2014) noted that web technology's effectiveness is still very potential to promote tourism products and destinations in Indonesia. So the strategic path for business people is sophisticated technology which is currently the best choice in doing business, such as in product target marketing.

However, the public, especially business people, must understand the tricks and business strategies that can take advantage of digital because there is a market segment that is not reached by traditional promotion. With the help of the right marketing technology that goes to the target customer and the marketing platform known to the world is digital. Thus all tourism products can be marketed quickly and cheaply. Énalan \& Soteriades (2012) prove that product tourism and international tourism destination marketing taken by digital means can be a new strategy under economic and productive approaches (Fandeli \& Mukhson, 2000; Timothy \& Boyd, 2015; Nurpratiwi et al., 2015). Because what is called a business must choose the principle of being thrifty and profitable. The next thing that business owners should do, such as how not to fail, where every tourist business driver understands and has a personal website and how they can become good social media people, can put it everywhere in social media advertisements. Digital can be maximized (Leung et al., 2015).

According to Ong \& Ito (2019) in this modern era where technology has become a general reference, a product's choice is in the public hand. So there is nothing wrong with an example of a good platform is social media. Because in social media networking there is also easy to get involved influencers who understand and are well-known in marketing efforts economically and practically. Another more meaningful way for business owners, especially tourism, is to know simple strategies and easy online marketing examples. For example, how they can understand the search and distribution of tourism trade content optima. It is up to the product, and then they should know how this typical search engine-based marketing relates to a bit of technology. They have to know the marketing strategy on social media, and then they are business people in the world of travel who have lots of connections somewhere in marketing, have email, have contacts like What is up to application marketing. That kind of thing is essential for everyone who wants to do online marketing, especially the tourism product business. (Hamouda, 2018). Understanding social media advertising effect on consumers' responses: An empirical investigation of tourism advertising on Facebook. Journal of Enterprise Information Management.

Apart from the best online advertising practices on well-known internet platforms, the traditional promotion method has been running (Di Pietro et al., 2012; Cropanzano \& Mitchell, 2005; Zakiah, 2020). However, now consumers feel that there is certainly something that is not right because the internet's presence as the most advanced technology can overcome many things, so customers must also open the internet both for information and for buying and selling affairs. They have to look at the version with technology first to save energy to make sure there is something free and inexpensive to spend just checking, booking, and reserving. So with something that is not expensive, they are sure to be able to transact into Indonesian tourism products. Some customers choose to do offline for their life needs with no internet service as the basis there; some people seem to remain everywhere. That's, for example, the reason they don't use the internet. Another reason could also be not having the skills to operate the internet.

What else is less than excellent, and then online marketing is changing very fast. Tourism business actors must follow the ways and demands of consumers and how business trends tend to change in an ever-changing technological era (Gay et al., 2007). Then some don't want to go online. They don't know people out there, so, be careful. This kind of internet business can be like so much crime that many cybercriminals do business online. Sometimes when a company is online, it tends to be so impersonal. We don't know exactly if it's not like that. Often we get to know clients or customers personally; we only know them through the digital platform. So customers also get a weakness is because they immediately order something that is not as they promised. In the end, these advertisements seem less effective because there is something like weakness, not precisely as they show on the promotion. But it happens most of the time we are not that careful, so it is a try sometimes for people, but it is just a weakness of being online.

What's in it for business people doing digital marketing software or strategies. Of course, there are many advantages. To support the business practice, Wymbs (2011) also said that digital marketing time is a new knowledge for business and academic discipline (Tiago \& Veríssimo, 2014; Kingsnorth, 2019). For example, they can get information so fast information only from international. Like almost every update, so we are always updated; with mobility, with changing situations, so many things happen due to natural disasters or something political, and something happens all over the world. So internet users come to know quickly only when they use digital. In the end, 
they become influential parties because they quickly understand the world updates compared to people who do not like doing business in the digital online way.

Chaffey \& Smith (2017) noted that the digital marketing practice can be a good way in making plans, optimization, and integration of online promotion. So to repeat here again, namely how to do marketing practices and what to do first to understand online marketing strategies. Then identify what people want to think when we say that marketing requires what most people want. Then do an online shop website which is the easiest way to promote an online store. Attend or bring the product to various forums many forums to exchange business transactions. So tourism business owners are there to determine what customers want to see. Do consumers buy, and what businesses sell? So digital marketing groups to maximize sales again. Those people in the business of providing service do not say what they do not sell. However, do not in the right way maximizes service and is honest when the business is not doing what the customer expects.

Before we go to the method section, we want to remind us why we chose digital software to promote business and tourism products. Watkins et al. (2018) answered that digital tourism is a critical factor in developing the national economy in a country rich in natural potential. Therefore the author must introduce a digital marketing strategy because it can provide more than what customers need in business solutions. The question is, why Indonesian tourism destinations and products have to promote online or on the internet? The answer is that Indonesia is a perfect natural resource tourism destination. It is excellent for showing a cultural story and much food that visitors cannot find in other countries outside of Indonesia. It is time to promote to foreign tourists that Indonesia's tourism sector has become Indonesia's most national foreign exchange. It is a reasonably good community based on a record of gross domestic product from the tourism sector each year. In this case, Antara \& Sumarniasih (2017) prove that the tourism sector's revenue has made Bali and Indonesia go global people destinations for tourism. That is the reason tourism is not only the following people who come here but also products to sell to the world then create more jobs; In the field of accommodation, transportation, restaurants, coffee shops, and local cultural attractions that have the potential to be promoted so that Indonesian domestic products are improved. Subawa et al. (2021) promoting tourism online is a real solution in the tourism sector. They answered with many study data on the tourism sector in Bali and other regional destinations in Indonesia.

Simultaneously, people today, especially the modern country they live in on the internet era. They only live in the technology to which access information and communicate so very fast that they do not have time to visit before because of the train so based on the data shows that the majority of people all over the world go traveling to countries after they look after them find out the information using a speedy information technology system which we call everything online. Brown \& Duguid (2017) confirm that the social life of information is no longer owned by limited circles but has been a global secret since the era of information and cutting-edge technology has gone global.

Because today consumers have everything they want by using the internet, there is no mistaking it for travel business managers to promote their products through technology derived from the internet. Vermesan \& Friess (2013) suggested that human life converges technologies for smart environments and integrated ecosystems Digitize all sectors of both economic and other interest services. This tourism sector business's economic opportunities will increase in Indonesia; there is no need to reason why people around the world do not know about Indonesia's tourist destinations and products. They only need to use the internet, so their choice will immediately increase to Indonesia, which is very attractive. So on that basis, why is our paper relevant in choosing online marketing to promote local products in the Indonesian tourism sector, which is changing?

It will be exciting for us to communicate through studies (Soeroso \& Susilo, 2014). Now we also explain another variable why we do internet promotion. This is because most people visiting other countries rely on information instinctively on their smartphones. So the best way to promote Indonesian tourism products is that the internet is an internet solution with various applications to inspire people worldwide quickly. Purwadi et al. (2017) noted that local tourism products could be promoted through multilingual applications. So that they no longer hesitate to choose Indonesia for the next distribution. For this reason, prospective travelers must know clearly, precisely what a particular country is like in Indonesia, so the first time they know, the first way they know is the internet and then.

Not surprisingly, if most people before going to other countries who first search for internet information make preparations, they will see promotional video content via software and other internet searches. This is very, very happy for many potential travelers. When tourists almost come to Indonesia, coming with friends, of course, contacting tourism organizers such as tour guide associations regarding bookings, locations, hotel reservations, cafes, and other supporting facilities (Wang et al., 2012). In essence, they must have previously gathered more information from various platforms and databases of other information about tourist destinations in Indonesia that are rich. 


\section{Method}

The software trend in increasing the marketing of tourism products in Indonesia is increasingly proven to be increasing and expanding. The study believes this trend is also happening in other parts of the world. To determine the validity of these data, we have reviewed several literature pieces in online reading sources. We have specialized in ten international published journals for the last ten years (2010 to 2020) to obtain data close to accuracy since digital trends have become more global and have widened their use in all business sectors, especially tourism. We selected secondary data by searching online from Google scholar, ERIC publications, Google Doc, and other databased sources. After the data is collected, the next analysis process involves understanding the questions, coding system, in-depth evaluation, and concluding. Our findings' size is limited to the lack of validity and reliability of data that have answered the questions in a qualitative descriptive manner. In all stages of data search and procedure, we follow the experts' directions in the field of data analysis by reviewing the narrative description. They include Xu et al. (2020) in their study of big data or small data in a review of tourism's sustainability method.

\section{Research Result}

The findings of Ankomah \& Larson (2019) prove that virtual tourism and its potential for tourism development in sub-Saharan Africa are very relevant to this study's hypothesis. In advanced methodologies and technologies in digital marketing and entrepreneurship. Their study focuses on how Sub-Saharan countries can explore virtual tourism. ICT-dependent tools extend tourism products and tourism experiences to the realm of online tourism. Software-based tours allow tourists to experience through their own. Their project reviews the literature on online travel and its relationship to digital and examines the ICT components that support virtual visits. Their final section recommends areas for virtual tourism research, and the final section provides concluding remarks.

Xiang et al. (2015) examined the relationship between information technology and consumer behavior in travel and tourism. Insights from planning trips using the internet. Maintaining business success depends on a company's ability to understand and capitalize on trends in consumer behavior. Combine information from multiple sources; this paper examines the nature of American tourists' use of the internet. In general, Internet usage has reached saturation levels, and some traditional channels such as online travel agencies (OTA) continue to dominate travel planning. While the traditional ways of using the internet for travel planning appear to be widespread across all customer segments, high-level Internet use (i.e., social media) is prevalent among some segments, particularly among Generation Y travelers. Additionally, there appear to be essential ramifications in the tourist population, whereas traditional online consumers remain unchanged with their online tool usage patterns while a sizeable group is adopting emerging sources of information and transaction channels. This article details these trends and offers managerial implications and directions for future research.

Meanwhile, Almeida-Santana \& Moreno-Gil (2017) study is a new trend in information seeking and its impact on destination loyalty: digital destinations and relationship marketing. Their finding was factual that social media influenced tourists' intentions to visit one destination rather than another. Travelers are consulting more digital information and using several different information sources, which affects the time travelers share across destinations. Social media has a more significant impact on attitude loyalty, according to the study. An extensive survey with 6964 questionnaires was developed, considering tourists from 17 European countries. The results will help make decisions regarding digital development strategies and loyalty programs to tourist destinations say the authors.

Likewise, Chuang et al. (2017) found that tourism's main route is to become a trend in tourism management through the internet. Their papers highlight critical research trajectories and themes in the context of eTourism. Evidence on websites, blogs, and social media about tourism is experiencing accelerating growth. The authors suggest a pendulum shift in which the asymmetry of information and negotiating power between the supply and demand sides moves from provider to consumer-centric.

Likewise, Burgess et al. (2011) examined the extent to which regional tourism organizations (RTOs) in Australia capitalize on the advantages of web technology for destination marketing and eCommerce. Travel and tourism have become the largest single product category sold over the internet, according to Tourism Australia. One study sought to determine whether and to what extent Regional Tourism Organizations in Australia are leveraging the benefits of Web technology for destination marketing and eCommerce. Despite the assertion that the Tourism industry is leading in terms of eCommerce adoption, it does not appear that Australian RTOs are slow to embrace eCommerce, the study said. The study results also add support to the premise that SMEs in this industrial sector typically start simply by building a presence on the Web and building functionality over time, as their experience and expertise in 
the use of Internet and Web technologies increases. This study was conducted over eight years from 2000 to 2008, using the Extended Model of Internet Commerce Adoption (eMICA).

The findings of Pirnar et al. (2012) who understand the increase in performance and competitiveness of tourism establishment through innovation, namely the trend of internet applications Innovation theory, can also describe changes in the service and tourism industries. Their study focuses on the application of innovation in the tourism industry by analyzing successful case studies. Innovation can be the introduction of lucrative markets for new products and services, better production techniques or processes, or better or more efficient ways of implementing marketing, communication and management strategies. The study provides suggestions for improving tourism agency performance through process innovation. They also see the case for tourism innovation as a result of the trend.

Evidence by Farkhondehzadeh et al. (2013) on E-Tourism examines the role of ICT in the tourism industry. Many tourism suppliers want to bypass the GDS route and use electronic distribution to sell directly to consumers. The potential now exists for tourism suppliers to directly distribute information and process reservations from customers, say the authors. Authors: Trends shaping modern business strategies such as mass customization services, interactive product design with customers, service coverage around the most basic of products, and increased intensity of product information apply to the tourism industry. They say ICT can support or activate these strategies and provide opportunities for growth in this area. The author analyzes the role of ICT in the tourism industry by introducing a framework for classifying and analyzing related organizations around three dimensions and describes some innovative ways to use ICTs to expand the actor's business.

Likewise, Xiang et al. (2015) adapt travel to the web through a pattern in the use of the web by explorers for travel planning. Indeed, the impact of the Internet on countries' social and monetary life is very much noted. However, there is not much research to evaluate how travelers have adapted to the Internet over time. Building on the development of general studies led in recent years (2007-2012), this investigation illustrates the significant changes taking place in the use of the Internet by American tourists. The results highlight critical patterns in Internet browsing usage and suggest "ramifications" developing between conventional online browsers, that is, individuals using the Internet for standard travel items and individuals starting to accept choices. Directs and items are seeking a more profound and more bona fide encounter. Their article examines some of the significant consequences of these patterns for exams and practice.

Likewise, the study of Dickinson et al. (2014) examined the travel industry and mobile applications: capabilities, emerging practices, and expansion in the field of movement. With their high-level processing capabilities and universality, mobile phones quickly become accepted as the travel industry's travel tool. With a growing number of clients and a wide variety of emerging uses, mobile phones generally match our current use and understanding of the travel industry's vehicle and travel organization. Based on a survey of cell phone applications, this article assesses the current functions used in the local travel industry's travel areas and the features where the following significant advances are located. At that point, on a more conscious level, the article examines how cell phones are intervening in the travel and work travel industry that it might play into more collective and dynamic travel choices to drive practical travel. Some of the research difficulties that arose were examined.

Parlov et al. (2016) tested a new pattern in travel industry destinations characterized by methods for computerized displays. It is fundamental to say exact words and propose new conditions in the computerized data market. This paper aims to introduce a new pattern in the travel industry's objective marking measure by leveraging methods for computerized advertising. The training examination showcases the travel industry-created countries showing a pattern in advanced advertising that can be used as a model for increasing the Croatian brand of the worldwide computerized travel industry. The results of Croatian training research in improving the objection travel industry concluded that there is still great potential to increase computerized marketing by setting up coordinated market correspondence techniques.

\section{Discussion}

In this section, a discussion of the findings of a review study aims to determine the relevance of digital software trends to increase Indonesian tourism destinations and products with several other countries through travel findings and hospital journal publications. Most of the papers emphasize a relationship and relevance between trends in internet technology adoption in advancing tourist destinations to their respective countries. Our data findings' novelty is to gain a deep understanding of how internet applications drive the world of tourism in the world. Whose names are religious; Trends in the digital, virtual, online, smartphone and several other names refer to the use of software in 
the tourism industry to increase national income and create fields for society, particularly for entrepreneurs and tourism products.

For example, Parlov et al. (2016) examined new examples of tourist businesses' target movement by examining strategic ways to present technology that automatically sells tourist information. It is essential to develop strong phrases and suggestions for new conditions in the mechanical information market. The purpose of this paper is to present new examples in measuring the business movement target stamp using automated application technologybased publication techniques. The assessment of activities showcasing website-based business movements carried out by other countries shows designs in cutting-edge digital publications that can serve as a model for brand development and tourism business products in Croatia as a whole including. The final result of the assessment of Croatian tourism activities in encouraging the tourism industry movement will get a bright spot that tourism potential will be great if it is managed in a modern way to increase national income so that tourism can advance in a modern way by establishing a market correspondence method arranged based on the information technology.

The truth of our opinion that digital trends have indeed become global in the business world, such as the promotion and marketing of tourism products, was also carried out by Troshin et al. (2020) with the theme of studying the role of information technology in advancing tourism products through the effectiveness of technology as an effective strategy to bring tourism closer to potential international travelers. Other studies such as Navío-Marco et al. (2018) examined how the development of information technology and the world of tourism management after a long period of internet technology has become a trend in the business world in many tourist destination countries.

\section{Conclusion}

It is repeated once again that this study's core objective is to understand the relevance of trends in digital technology or software to increase the marketing of tourism and hospitality products in the world with the tourism industry in the country. Our hypothesis is confirmed that many countries have applied technological sophistication to enhance their tourism. We do this proof by studying much literature and especially in ten international travel journal publications. Almost all of the journals we have reviewed confirm that there is no more effective way to introduce tourism in the country other than adopting technology with all application system models called digital, vertical, software, and others. With these findings, it is increasingly convincing the world of tourism and hospitality in Indonesia to wholeheartedly adopt technology so that their tourism products in the country will be the best for visiting Indonesia so that the income and welfare of tourism drivers can progress successfully.

\section{Acknowledgments}

We want to express our deep gratitude for the participation of ideas and academic support given by friends so that this business and technology study paper can be prepared on target. Likewise, the source of sponsorship funds that have been given so that we can be very helpful during the study's excellent work to the reporting that we dream about with the theme "Software Trends in Improving Local Tourism Product Marketing in Indonesia: a Systematic Review."

\section{References}

Adi, S. (2014). Evaluation on the effectiveness of the web technology usage in promoting and marketing indonesia tourism. Journal of Theoretical \& Applied Information Technology, 68(3).

Almeida-Santana, A., \& Moreno-Gil, S. (2017). New trends in information search and their influence on destination loyalty: Digital destinations and relationship marketing. Journal of Destination Marketing \& Management, 6(2), $150-161$.

Ankomah, P., \& Larson, T. (2019). Virtual tourism and its potential for tourism development in sub-saharan africa. In Advanced methodologies and technologies in digital marketing and entrepreneurship (pp. 584-595). IGI Global.

Antara, M., \& Sumarniasih, M. S. (2017). Role of tourism in economy of Bali and Indonesia. Journal of Tourism and Hospitality Management, 5(2), 34-44.

Bassano, C., Barile, S., Piciocchi, P., Spohrer, J., Iandolo, F., \& Fisk, R. (2019). Storytelling about places: Tourism marketing in the digital age. Cities, 87, 10-20. https://doi.org/10.1016/j.cities.2018.12.025

Brown, J. S., \& Duguid, P. (2017). The social life of information: Updated, with a new preface. Harvard Business Review Press.

Benur, A. M., \& Bramwell, B. (2015). Tourism product development and product diversification in destinations. Tourism management, 50, 213-224. https://doi.org/10.1016/j.tourman.2015.02.005 
Chaffey, D., \& Smith, P. R. (2017). Digital Marketing Excellence: Planning, Optimizing and Integrating Online Marketing. Routledge.

Chuang, T. C., Liu, J. S., Lu, L. Y., Tseng, F.-M., Lee, Y., \& Chang, C.-T. (2017). The main paths of eTourism: Trends of managing tourism through Internet. Asia Pacific Journal of Tourism Research, 22(2), 213-231.

Cropanzano, R., \& Mitchell, M. S. (2005). Social exchange theory: An interdisciplinary review. Journal of Management, 31(6), 874-900.

Di Pietro, L., Di Virgilio, F., \& Pantano, E. (2012). Social network for the choice of tourist destination: Attitude and behavioural intention. Journal of Hospitality and Tourism Technology.

Dickinson, J. E., Ghali, K., Cherrett, T., Speed, C., Davies, N., \& Norgate, S. (2014). Tourism and the smartphone app: Capabilities, emerging practice and scope in the travel domain. Current Issues in Tourism, 17(1), 84-101.

Énalan, D., \& Soteriades, M. (2012). Tourism destination marketing: Approaches improving effectiveness and efficiency. Journal of Hospitality and Tourism Technology.

Fandeli, C. \& Mukhson. (2000). Tourism Administration. Offset Student Library.

Farkhondehzadeh, A., Robat Karim, M. R., Roshanfekr, M., Azizi, J., \& Legha Hatami, F. (2013). E-Tourism: The role of ICT in tourism industry. European Online Journal of Natural and Social Sciences, $2(3$ (s)), pp-566.

Gay, R., Charlesworth, A., \& Esen, R. (2007). Online Marketing: A Customer-Led Approach. OUP Oxford.

Hamouda, M. (2018). Understanding social media advertising effect on consumers' responses: An empirical investigation of tourism advertising on Facebook. Journal of Enterprise Information Management.

Hassan, A., \& Rahimi, R. (2016). Consuming "Innovation" in tourism: Augmented reality as an innovation tool in digital tourism marketing. In Global dynamics in travel, tourism, and hospitality (pp. 130-147). IGI Global.

Hifza, Juliana, Palapa, A., Maskur, \& Aslan. (2020). The Strategic Foundation for Competitive Excellent Development in Integrated Islamic Primary Schools in Indonesia. International Journal of Advanced Science and Technology, 29(12s), 1747-1753.

Hudson, S., \& Hudson, L. (2017). Marketing for tourism, hospitality \& events: A global \& digital approach. Sage.

Kingsnorth, S. (2019). Digital Marketing Strategy: An Integrated Approach to Online Marketing. Kogan Page Publishers.

Lau, G. T., \& Lee, S. H. (1999). Consumers' trust in a brand and the link to brand loyalty. Journal of MarketFocused Management, 4(4), 341-370.

Leung, X. Y., Bai, B., \& Stahura, K. A. (2015). The marketing effectiveness of social media in the hotel industry: A comparison of Facebook and Twitter. Journal of Hospitality \& Tourism Research, 39(2), 147-169.

Navío-Marco, J., Ruiz-Gómez, L. M., \& Sevilla-Sevilla, C. (2018). Progress in information technology and tourism management: 30 years on and 20 years after the internet-Revisiting Buhalis \& Law's landmark study about eTourism. Tourism Management, 69, 460-470.

Nurpratiwi, R., Wijaya, A. F., \& Putra, S. M. (2015). Tourism Destination Management (Case Study in Department of Culture and Tourism Pasuruan Regency). Journal of Indonesian Tourism and Development Studies, 3(1), 29352.

Ong, Y. X., \& Ito, N. (2019). "I want to go there too!" Evaluating social media influencer marketing effectiveness: A case study of Hokkaido's DMO. In Information and communication technologies in tourism 2019 (pp. 132-144). Springer.

Okumus, B., Okumus, F., \& McKercher, B. (2007). Incorporating local and international cuisines in the marketing of tourism destinations: The cases of Hong Kong and Turkey. Tourism management, 28(1), 253-261. https://doi.org/10.1016/j.tourman.2005.12.020

Parlov, N., Perkov, D., \& Sičaja, Ž. (2016). New trends in tourism destination branding by means of digital marketing. Acta Economica Et Turistica, 2(2), 139-146.

Pirnar, I., Bulut, C., \& Eris, E. D. (2012). Improving the performance and competitiveness of tourism establishments by means of innovation: Trends and applications. Proceedings of IRAT „Enlightening Tourism "Conference, Naples, Italy, 211.

Purwadi, P., Novianty, A., Nugraha, D. A., \& Lestari, Y. (2017). Local tourism promotion through multilingual vlog in Garut, Indonesia. ASEAN/Asian Academic Society International Conference Proceeding Series.

Pyke, S., Hartwell, H., Blake, A., \& Hemingway, A. (2016). Exploring well-being as a tourism product resource. Tourism Management, 55, 94-105. https://doi.org/10.1016/j.tourman.2016.02.004

Royo-Vela, M. (2009). Rural-cultural excursion conceptualization: A local tourism marketing management model based on tourist destination image measurement. Tourism management, 30(3), 419-428. https://doi.org/10.1016/j.tourman.2008.07.013 
Smith, S. L. (1994). The tourism product. Annals of tourism research, 21(3), 582-595. https://doi.org/10.1016/01607383(94)90121-X

Slater, S. F., \& Narver, J. C. (1995). Market Orientation and the Learning Organization. Journal of Marketing, 59(3), 63-74. JSTOR. https://doi.org/10.2307/1252120

Soeroso, A., \& Susilo, Y. S. (2014). Traditional Indonesian gastronomy as a cultural tourism attraction. Editorial Board, 45.

Subawa, N. S., Widhiasthini, N. W., Astawa, I. P., Dwiatmadja, C., \& Permatasari, N. P. I. (2021). The practices of virtual reality marketing in the tourism sector, a case study of Bali, Indonesia. Current Issues in Tourism, 1-12.

Tiago, M. T. P. M. B., \& Veríssimo, J. M. C. (2014). Digital marketing and social media: Why bother? Business Horizons, 57(6), 703-708.

Timothy, D. J., \& Boyd, S. W. (2015). Tourism and trails: Cultural, ecological and management issues (Vol. 64). Channel View Publications.

Todor, R. D. (2016). Blending traditional and digital marketing. Bulletin of the Transilvania University of Brasov. Economic Sciences. Series V, 9(1), 51.

Toffler, A. (1970). Future Shock. Bantam Books.

Toffler, A. (1980). The Third Wave. William Morrow and Company, INC.

Vermesan, O., \& Friess, P. (2013). Internet of things: Converging technologies for smart environments and integrated ecosystems. River publishers.

Wang, D., Park, S., \& Fesenmaier, D. R. (2012). The role of smartphones in mediating the touristic experience. Journal of Travel Research, 51(4), 371-387.

Watkins, M., Ziyadin, S., Imatayeva, A., Kurmangalieva, A., \& Blembayeva, A. (2018). Digital tourism as a key factor in the development of the economy. Economic Annals-XXI, 169, 40-45.

Wymbs, C. (2011). Digital marketing: The time for a new "academic major" has arrived. Journal of Marketing Education, 33(1), 93-106.

Xiang, Z., Magnini, V. P., \& Fesenmaier, D. R. (2015). Information technology and consumer behavior in travel and tourism: Insights from travel planning using the internet. Journal of Retailing and Consumer Services, 22, 244249.

Xu, F., Nash, N., \& Whitmarsh, L. (2020). Big data or small data? A methodological review of sustainable tourism. Journal of Sustainable Tourism, 28(2), 144-163.

Zakiah, S. et, al. (2020). Social media as an effective tourism marketing in the digital era. International Journal of Advanced Science and Technology, 29(2), 753-766. 